Specijalna edukacija i rehabilitacija

UDK: 615.851:73/.79

(Beograd), Vol. 12, br. 2. 221-240, 2013.

ID: 199917836

Stručni članak

Damir MIHOLIĆ

doi:10.5937/specedreh12-3506

Renata MARTINEC ${ }^{1}$

University of Zagreb

Faculty of Education and Rehabilitation Sciences

Croatia

\title{
SOME ASPECTS OF USING EXPRESSIVE ARTS-THERAPIES IN EDUCATION AND REHABILITATION
}

Contemporary approaches in different fields of expressive artstherapies (art-therapy, music therapy, dance movement therapy, bibliotherapy, psychodrama and drama therapy) are presented in this article. In that way, theoretical background, some elements of observation and assessment, as well as specific methods of therapy interventions are described. Relevant knowledge about different aspects of expressive art-therapies is presented by reviewing some recent references and results of different investigations. Results of previous researches pointed out that expressive arts-therapy may have positive influence on different aspects of psychosocial functioning. Also, further investigations are needed in order to achieve best practice in different fields of education and rehabilitation.

Key words: expressive arts-therapies, creative arts, methods, evaluation

1 E-mail: renata.martinec@zg.t-com.hr 


\section{INTRODUCTION}

„...When words are not enough, we turn to images and symbols to tell our stories. And in telling our stories through art, we find pathways to wellness, recovery and transformation..."

Malchiodi, C. (2012)

Expressive arts therapies or creative arts therapies, is a model of using the expressive arts as a form of therapy. International Expressive Arts Therapy Association (IEATA) (2012a) defines expressive artstherapies "as methods of using the visual arts, music, dance/movement, drama, poetry, writing and other creative processes to foster deep personal growth and community development" (Figure 1).

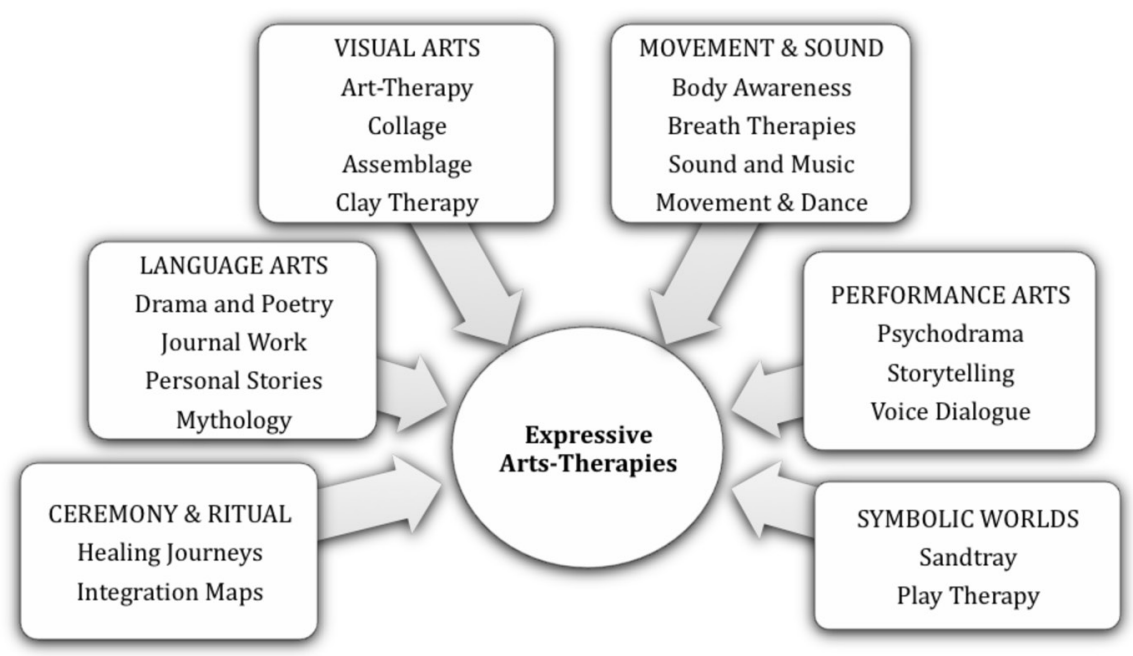

Figure 1 - Some approaches in Expressive Arts-Therapies

Expressive arts-therapies are predicated on the assumption that through creative expression and tapping of imagination, a person can examine different aspects of Self such as „sensory experiences, symbolic expression, emotional expression, life enhancement, cognitive development and social connectedness" (Karkou \& Sanderson, 2006). Many factors 
can be considered in the frame of expressive arts-therapies, e.g. principles of play, improvisation, time, space, aesthetics, imagination, mind/body connections, aspects of experimentation, risk taking, discovery, and meaning making (Knill at al., 2005; Kossak, 2009).

Therefore, and regarding the results of some scientific investigations, expressive arts-therapies could be considered as a beneficial diagnostic and therapeuticapproach in different problem areas in the field of physical, perceptual, cognitional, emotional and behavioural functioning.

The application of expressive arts-therapies in different areas of therapy, education and rehabilitation has increased in the past few years. Also, a great effort has been made to support multimodal expressive arts process for personal and community transformation, focusing on the education of experts in different disciplines. In that way, the International Expressive Arts Therapy Association (IEATA) (2012b) provides“... a global forum for dialogue, promotes guiding principles for professional practice, and works to increase recognition and use of expressive arts as a powerful tool for psychological, physical and spiritual wellness". Now, approximately 70 study programmes at undergraduate or graduate levels are provided at about 50 different university departments.

Generally, expressive arts-therapies could be one of the valuable approaches in different areas of therapy, education and rehabilitation, especially in the field of emotional disturbances, behavioural disorders, attention deficit and hyperactivity disorder (ADHD), chronic diseases, learning disabilities, eating disorders, abuse, etc.

\section{EXPRESSIVE ARTS-THERAPY}

According to the International Expressive Arts Therapy Association (IEATA) (2012a), the expressive arts-therapies include a set of individual approaches defined as: art therapy, music therapy, dance/movement therapy, psychodrama/drama therapy and bibliotherapy. Additionally, expressive therapies are sometimes referred to as ,integrative approaches“ or "multimodal approaches" when they purposively involve two or more expressive tools to foster awareness, encourage emotional growth, and enhance relationships with others (Malchiodi, 2012). 
Specijalna edukacija i rehabilitacija (Beograd), Vol. 12, br. 2. 221-240, 2013.

\section{Art-therapy}

Drawing and painting, along with music and dance, are one of the oldest media of human communication with nature, supernatural and transcendental world of existence. Also, in contemporary approaches, the main goal of using these kinds of art-media is understanding of inner motivation, as well as emotional and behavioural impulses.

American Art Therapy Association (AATA) (2012) defines art-therapy: „....as therapeutic use of art media, images, and the creative process respecting client responses to the created products as reflections of development, abilities, personality, interests, concerns, and conflicts. Art-therapy integrates the fields of human development, visual art (drawing, painting, sculpting, and other art forms), and the creative process with models of counselling and psychotherapy".

Also, according to AATA (2012), different approaches in the frame of art-therapy could be helpful in the process of:

- coping with the symptoms and traumatic experience

- exploring pathways of self-expression

- enhancing motivation

- reconciling emotional conflicts

- developing social skills

Materials and interventions appropriate to clients' needs and session protocol can be chosen in art-therapy. Also, some specific diagnostic instruments can be used in the frame of art-therapy. One of the first is Goodenough test Draw-A-Man (1926) aimed at measuring intellectual/mental maturity (Malchiodi, 1998). Also, there are some projective tests that refer to personal experience, e.g. House-Tree-Person Test (Malchiodi, 2012), Draw-A-Person Test (Machover, 1949), Draw-ATree Test (Pražić, 1987), Draw-A-House Personality Test (Pražić, 1987), Draw-A-Family Test (Lachowska, 2002), The Mandala Assessment Research Instrument (MARI) (Guerra, 2010), etc.

In these tests, motives are just symbols that induce mechanisms of projection, introjections and identification at imagination level. They are used as tools of provoking introspection, verbalization and elaboration at somatic, symbolic and realistic levels. That means that the interpretation of clients' drawing goes beyond iconographic form by analyzing different quantitative and qualitative variables which could include the following elements: 

a) motive - oneself, other people, animals, or other objects
b) colour - number and preference of using colours, symbolic meaning of colours
c) figurative or abstract form
d) placement on the paper and dimension of figures
e) shapes and lines - length, direction, intensity of pressing, quality of lines, enclosure
f) symmetry and composition
g) omission, deletion, shading, fixing up, etc.

Art-therapy could be useful in a wide range of difficulties such as: emotional, behavioural or mental health disorders, ageing, physical disabilities, chronic disease, body-image disorders, physical diseases (Eathon at al., 2007; Kim at al., 2008; Knill at al., 2005). It is also stressed that this kind of therapy could be useful in people who have a sense of control loss because, according to Karkou and Sanders (2006), it can assure a "map" of identifying the changes that are needed, and how to manage the changes that are not self-destructive or ineffective.

Diagnostic and therapeutic benefits of art-therapy are also proved in education, dealing with different problems e.g. attention disorder, speech and language disorder, learning disabilities, and varied emotional disorders that could hinder child's learning (Kazim, 2002; Knill at al., 2005; Malchiodi, 2012).

\section{Music therapy}

According to the World Federation of Music Therapy (WFMT) (2013), „music therapy is the professional use of music and its elements as an intervention in medical, educational, and everyday environments with individuals, groups, families, or communities who seek to optimize their quality of life and improve their physical, social, communicative, emotional, intellectual, and spiritual health and wellbeing".

Music therapy includes a wide range of interventions, e.g.: receptive music listening, music improvisation, song writing, singing, rhythmic based activities, combination of music and guided imagery, music performance, composing, etc.

Music therapy can be organised in individual or group sessions. Ongoing individual music therapy session is effective because it provides 
Specijalna edukacija i rehabilitacija (Beograd), Vol. 12, br. 2. 221-240, 2013.

non-distractive and non-judgmental environment in which a client is encouraged to show capacities that may be disabled in a group setting. Group music therapy can also engage group discussion regarding moods and emotions, and it is a powerful way of strengthening group cohesion and social skills (Ledgar \& Edwards, 2011).

Results of some investigations (Austin, 2010; Chrichley \& Henson, 1982; Rüütel, 2002) showed that effects of music can be beneficial at different levels of psycho-physiological functioning:

- Rhythm and tempo can stimulate brainwaves to resonate in synchrony with the beat, e.g. faster beats bring sharper concentration and more alert thinking, and a slower tempo promotes a calm, meditative state. Also, the change in brainwave activity levels that music can cause can also enable the brain to shift speeds more easily on its own as needed, which means that music can bring lasting benefits to the state of mind, even after the listening is finished.

- Induced differences in brainwaves could provoke changes in other bodily functions especially those governed by the autonomic nervous system. That means that different elements of music (sounds, rhythm, tempo, melody and harmony, etc.) may inhibit or facilitate the intensity of different function such us: breathing, heart rate, blood pressure, muscle tension, etc.

- Music can be a useful tool of facilitating relaxation, introspection, creativity and optimism levels.

The results obtained in different empirical and scientific investigations proved that music therapy can be useful in many areas such us: overall physical rehabilitation and facilitating movement, increasing one's motivation to be engaged in treatment, providing emotional support for clients, and providing an outlet for expression of feelings. For example, data of some investigations suggest that group music therapy can support self-expression and provide a channel for transforming frustration, anger, and aggression into the experience of creativity and self-mastery (Montello \& Coons, 1998). Field at al. (1998) described that youth with symptoms of depression listening to music showed a significant decrease in stress hormone (cortisol) levels, and most adolescents shifted toward left frontal EEG activation (associated with positive affect). 
With the purpose of analysing the effects of music therapy in children and adolescents with different kind of psychopathology, Gold (2007) provided an overview of 10 previous studies conducted in the last 30 years. The studies included in this review comprise the samples of investigation that were, related to diagnosis, divided in three categories: behavioural disorders, emotional disorders, and developmental disorders. The data of this investigation showed that music therapy with these clients has a highly significant, medium to large effect on their psychological states. Music therapy was most effective on subjects with mixed diagnoses, and the effects of music therapy are more enduring when more sessions are provided.

Music therapy can also facilitate some social skills, such as interpersonal understanding and group cohesion. Silverman (2009) describes the results of research in which connections between compassion expressions and the use of music within the children with special needs in integration group were found. Similarly, Wigram (2002) stressed that this kind of therapy could be a valuable approach for children with disabilities because fosteing capacity for flexibility, creativity and tolerance of change can be a useful tool of balancing the more structured and behaviourally driven education required in school settings.

Also, since music is non-figurative art and because it can have a meditative character, it is often used as a stimulating or supportive tool in using other arts-therapies interventions.

\section{Dance movement therapy}

Dance Movement Therapy (DMT) includes using and analyzing different aspects of body-experience and body-expression such us movement, posture, gesture, mimics, pantomime, touch, etc. According to the thesis on body-mind unit, the American Dance Therapy Association (ADTA) (2012) defines Dance Movement Therapy: ,... as the psychotherapeutic use of movement to further the emotional, cognitive, physical and social integration of the individual".

In DMT body is the dominant media of therapeutic process. Thus, it may have a positive influence on physiological awareness, body expression of emotions, inducing unconscious impulses, and improving 
Specijalna edukacija i rehabilitacija (Beograd), Vol. 12, br. 2. 221-240, 2013.

new strategies of behaviour through exploring new patterns and qualities of movement.

Pylvänäinen (2010) suggests the following list of benefits that DMT may have:

- release - relaxation which relates to the calming of the state of the autonomous nervous system

- induce images, memories, associations

- facilitate symbolic expressions of the self

- $\quad$ play with different ways of experiencing and encountering the world

- discovering the new ways of being and acting in interaction

- activate relationship to oneself: what one discovers in oneself, movement expressions of this, connectedness to the bodyself/core-self

- $\quad$ induce reflections in words of these experiences

- learn how to be in the body in the present

With the aim of developing the evaluation criteria, great attention is directed at the specific system of movement quality observation. One of the basic models is Laban Movement Analysis (LMA) developed with the aim to observe, note, and analyze different substances of movement (Maletić, 1983; Newlove \& Dalby, 2004). This model, also called shape - effort, is focused on three main categories of observation:

a) body shape - there are four distinct body shapes - narrow, wide, curve, and twist - particularly important with regard to emotional states, attitudes and energy capacity.

b) space - ways in which the body can move from one designated point to another. Main areas are: forward, centre; back, sideto-side; left-right; high-middle-deep; vertical-horizontal-sagittal plane.

c) effort - qualitative or dynamic aspects of movement - describe four movement factors: space (direct-indirect), time (suddensustained), weight (strong-light), and flow (bound-free).

In the process of observation and evaluation it is also important that the following variables are included: posture, gesture, mimics, eye contact, facial expression, physical sensations, interactions with other person, dominant body part in action, dynamics and kinaesthetic energy, body-image and body awareness, etc. 
Depending on the session protocol, the client's needs and proneness, and therapy process adaptation, some specific methods of interventions can be used, such as:

a) Imitation - physical imitation (reflexion) of the mover's entire shape, form or effort factors in exact synchrony and simultaneity with the purpose that the observers, through kinaesthetic empathy, sense and match the mover's movement patterns and feelings (Fischman, 2009).

b) Mirorring - process when one person embodies the specific shapes, patterns and movement qualities of the other person with the aim of understanding and connecting with psychological background of a person's movement. In mirroring, the observer performs the mover's set of movement but some characteristic shape of effort quality could be stressed, exaggerated or performed in different intensity (Tortora, 2009).

c) Body-symbolisation - using the specific posture, gesture, mimics and movement that are characteristic of experiencing and expressing one's own emotions (Martinec, 1995).

d) Movement exploration - analyzing how different kind and quality of movement affect one's own feelings, associations and memories (Tortora, 2009).

e) Authentic movement - using free movements that are spontaneous. The impulse for authentic movement arises from specific body-part needs, intrinsic value and symbolic material (Capello, 2009). It is based on imagination and improvisation, facilitating creative liberation and self-expression.

Although DMT is mainly a psychotherapeutic approach, specialized treatments also can help cure and aid many types of diseases and disabilities (Hervey, 2009). This multiple influence could also be explained by admitting the importance of movement in ontogenetic human development. So, therapeutic use of specific movement or sets of movement can induce or support emotional but also cognitive function and social skills. In that way Behrends at al. (2012) stressed that: "Characteristic elements of movement and dance (e.g. imitation, synchronous movement and motoric cooperation) are suitable for fostering empathic abilities and interpersonal communication".

Generally, DMT may have influence on the sense of acceptance, organizationalskills, sense of controland choice, body-image, coordination 
Specijalna edukacija i rehabilitacija (Beograd), Vol. 12, br. 2. 221-240, 2013.

and motor skills, symbolic meanings and self-expression. Therefore, the improvement in different aspects of physical and psychological wellbeing by using DMT is proved in the field of learning disabilities, hearing or visual impairments, physical disabilities, pervasive developmental disorder, geriatrics, stress management and different mental disorders (Behrends at al., 2012; Bräuninger, 2012; Hervey, 2009; Tortora, 2009).

\section{Drama, psychodrama and drama therapy}

The dramatic experience of the world is one of the inborn human characteristics, and as Robinson vividly explains (as cited in Krušić, 1992, p. 267) ,... we have the basic ability to dramatize our language and gesture ... it's ability to represent, thanks to which, an action or experience can be substituted or means another action or experience. This ability arises in early childhood as a symbolic play and runs until maturity and after as the ability to take the role..."

Through action and expression in dramatic action that takes place in an imaginary, dramatic world, experience and knowledge are shaped at the level of different components of human personality: cognitive, emotional, physical and social. Creating the world of drama is realized by placing signs for space, people or emotions. These signs become symbols and allow understanding of deeper meaning of existence and the possibility for personal change. As Jennings (1992) states, cognition oversteps the distance between a play (imaginary world) and the world of personal experience, and creates a paradoxical situation in which, through distancing, we approach ourselves. Dramatic experience is an observing where ,...the human being perceives what it is, discovers what it is not and imagines what it could become" (Boal, 1995, p.13).

Also, dramatic experience is the potential opportunity for change, what Aristotle called catharsis (gr. kathairo - clean). In an individual or a

group setting, dramatic world is observing, experimenting, developing and changing.

In recent years, various theatrical concepts which use theatre as a tool change the audience into active participants of the drama. The spectator becomes an actor and/or director, with the aim of provoking, learning, rehabilitating and undergoing therapy. The beginning of a systematic application of drama in the context of education dates 
back to the 50s and the work of Peter Slade and his book "Child Drama“ (1954). He tried to examine child development through dramatic phenomena and made groundwork for the application of drama as a method which encourages child development at various levels, up to the implementation of this method in the school curricula.

By analysing practical work of different authors, Krušić (2002) states that dramatic activities could be understood as an efficient method which enables a child to develop:

- expression of feelings, preferences, abilities and attitudes

- speech and expressive abilities and skills

- imagination and creativity

- motor skills and „body language“

- social awareness and its components (criticism, self-criticism, responsibility and tolerance)

- human moral beliefs

- security and confidence, understanding of human relationships and behaviour, learning how to work together, respect oneself and others and thus gain the recognition of others.

Through the dramatic process of forming an imaginary world, the client's real world is considered through the process of projection (characters, objects, puppets) and transformation (the process of understanding, experiencing and changing dramatic material, and the relationship with the therapist and the group members).

Jones (1996) describes a repertoire of expressive dramatic form which can be used in drama therapy:

- the use of created and scripted roles and characters or playing oneself in a fictional reality

- the use of materials such as objects, small toys and puppets

- the use of a body in dramatic form through disguise, masking, mime or performance

- the use of scripts, stories and myths and the creation of dramatic rituals.

One of the elements of drama therapy can be a puppet that facilitates communication between a child and a therapist. The puppet represents an extension of self and a transitional object which connects the imagination and reality (Prstačić i sar., 1991). By the processes of projection and identification, the child is able to present events, 
Specijalna edukacija i rehabilitacija (Beograd), Vol. 12, br. 2. 221-240, 2013.

elaborate them and get the opportunity and the ability to transform. The puppet can be any object in the environment. The most commonly used in therapy are hand puppets - guignol, rod puppets, and finger puppets.

Psychodrama is one of the methods of applying dramatic experience in therapy. Founder of psychodrama, Jacob Levy Moreno defined it as ,the science which explores the truth by dramatic methods" (as cited in Kellerman, 1992, p. 17). A more complex definition is given by Kellerman (1992, p. 20): „Psychodrama is a method of psychotherapy in which the clients are encouraged to continue and complete their actions through dramatization, role playing, and dramatic self presentation." Problem situations from everyday life, within a group or individually, are processed through the application of techniques such as role reversals, double, mirroring, amplification, etc. The base for psychodrama is the concept of role, defined by Moreno as the functional form of behaviour which an individual assumes at a specific moment in response to specific situation he/she is involved in (Greeberg, 1975).

According to Blatner (2000) Moreno distinguishes three types of roles:

1) psychosomatic roles (related to satisfaction of basic needs food, sleep, etc., and nonverbal expression),

2) social roles (most of the roles from our social life),

3) psychodrama roles (refer to roles outside the real world, which finds its place in imagination).

Moreno's thesis is that the more roles in life we are able to realize the more comprehensive our personality is. Through different psychodrama techniques, in a safe group environment, a client may spontaneously adopt and modify certain role or spectrum of roles and specific forms of behaviour, perception and expression which characterize us or others in everyday life.

Drama therapy and psychodrama can be applied to individuals and groups in educational institutions, clinics, hospitals, rehabilitation centres etc., and can include different population of clients such as children, adolescents and adults with emotional and mental problems, learning disabilities, speech impairments, physical disabilities, sensory impairments and chronic diseases. 


\section{Bibliotherapy}

By definition, bibliotherapy is a part of expressive arts-therapy that uses a dynamic personal relationship between the client and the content of prose, poetry, drama, myth and other type of literature for therapeutic purposes.

„Bibliotherapy“ as a term was first used by Samuel Crothers 1916. (Pehrsson \& McMillen, 2005). Main elements of definition and therapeutic processes in bibliotherapy were explained by Shrodes as „processes of identification/universalization, catharsis/abreaction and insight/integration" (as cited in Pehrsson \& McMillen, 2005, p. 50). Identification is related to the moment of recognition of similarities between characters and/or situations from the text and the client's life. In catharsis, the client is highly emotionally engaged with the character's story and shares that emotion with the therapist and the group (if therapy is in a group setting), which leads to the insight and creative understanding of the character's situation and possibilities for positive solutions. Shechtman (2009) varies levels of projection, depending on the type of chosen literature. For example, stories (novel, short stories, fables, fairytales, etc.) offer clear structure (introduction in the situation at the beginning; rise of conflict and expression of characters in the middle and resolutions with emotional relief at the end), while poetry is more ambiguous and offers a wider frame for projections of thoughts and emotions.

Caldwell (2005) describes the concept in which narrative therapy and expressive arts-therapies could be applied in cultivating and supporting creativity in life review process. The counsellor acts in a co-creative and consultative role, drawing on the client's expertise about his or her own life and constructing a collaborative process that can also engage the client's family, caregivers, and important others in the client's community. The author suggests some approaches such as: bibliotherapy, journaling, making of memory books, self boxes, life maps, and time capsules, along with video-graphy as a myriad of ways to tap into an ongoing creative meaning-making process necessary for life review. It is concluded that these techniques could be helpful in the process of deconstructing problems and constructing unique outcomes for the client and others involved in the problem situation. 
Specijalna edukacija i rehabilitacija (Beograd), Vol. 12, br. 2. 221-240, 2013.

Pehrsson and McMillen (2005), considering the results of different authors, suggest a wide range of problem fields for bibliotherapy application. Some of them are: aggressiveness, adoption/foster care, death and dying, addictions, conflict resolution, child abuse/neglect, separation and loss, self-awareness, development of ethnic/cultural, stress, anxiety, loneliness, coping skills, interpersonal skills, emotional maturity etc.

\section{CONSLUSION}

Arts are considered a fundamental phenomenon of human existence and are closely related to imagination, emotion, cognition, body-experience and spirituality. Symbolic expression enables overcoming limitations of standard communication and can precisely, at deeper level, illuminate inner and outer conflicts and possible solutions of the problem. Painting, music improvisation, dance, making stories, role playing etc., can facilitate verbal and non-verbal channels of communication with oneself and others.

Having influence on physiological, psychosocial and cognitive functions, expressive arts-therapies could be one of the valuable approaches in different areas of therapy, education and rehabilitation, especially in the field of emotional disturbances, behavioural disorders, attention deficit and hyperactivity disorder (ADHD), chronic diseases, learning disabilities, body-image disturbances, eating disorders, abuse etc. Furthermore, this approach can be generally useful in discovering and supporting the mechanisms of self-actualisation and adaptive potentials development. Also, further investigations are needed in order to achieve best practice in different fields of education and rehabilitation. 


\section{REFERENCES}

1. About Dance/Movement Therapy. American Dance Therapy Association (ADTA). Retrieved, December 9, 2012 from http:// www.adta.org

2. What is Art-therapy? American Art Therapy Association (AATA). Retrieved November 21, 2012. from http://www.arttherapy.org

3. Austin, D. (2010). The psychophysiological effects of music therapy in intensive care units. Paediatric Nursing, 22 (3), 14.20.

4. Behrends, A., Muller, S., \& Dziobek I. (2012). Moving in and out of synchrony: A concept for a new intervention fostering empathy through interactional movement and dance. The Arts in Psychotherapy, 39 (2), 107-116.

5. Blatner, A. (2000). Foundations of Psychodrama. New York: Springer Publishing Company.

6. Boal, A. (1995). The rainbow of desire. London:Routledge.

7. Bräuninger, I. (2012). Dance movement therapygroup intervention in stress treatment: A randomized controlled trial (RCT). The Arts in Psychotherapy, 39 (5), 443-450.

8. Caldwell, R. L. (2005). At the confluence of memory and meaning - Life review with older adults and families: Using narrative therapy and the expressive arts to re-member and re-author stories of resilience. The Family Journal, 13, 172-175.

9. Capello, P. P. (2009). BASCICS - An intra/interactional model of DMT with adult psychiatric patient. In S. Chaiklin \& H. Wengrower (Eds.), The art and science of dance movement therapy (pp. 77-102). New York - London: Routhlidge.

10. Chaiklin, S., \& Wengrower, H. (2009). Introduction. In S. Chaiklin $\& \mathrm{H}$. Wengrower (Eds.), The art and science of dance movement therapy (pp. xv-xviii). New York - London: Routhlidge.

11. Chrichley, J., Henson, E. (1982). Music and the Brain. London: Heinemann Medical Book Ltd.

12. Eaton, L.G., Doherty, K. L., \& Widrick, R.M. (2007). A review of research and methods used to establish art therapy as an 
Specijalna edukacija i rehabilitacija (Beograd), Vol. 12, br. 2. 221-240, 2013.

effective treatment method for traumatized children. The Arts in Psychotherapy, 34 (3), 256-262.

13. Field, T., Martinez, A., Nawrocki, T., Pickens, J., Fox, N.A., \& Schanberg, S. (1998). Music shifts frontal EEG in depressed adolescents. Adolescence, 33 (129), 109-116.

14. Fischman, D. (2009). Therapeutic relationship and kinaesthetic empathy. In S. Chaiklin \& H. Wengrower (Eds.), The art and science of dance movement therapy (pp.33-53). New York - London: Routhlidge.

15. Gold, C., Wigram, T., \& Voracek, M. (2007). Predictors of change in music therapy with children and adolescents: the role of therapeutic techniques. Psychology and Psychotherapy: Theory, Research and Practice, 80, 57-589.

16. Greenberg, I.A. (1975). Other Theoretical Specifics. In: Psychodrama - Theory and Therapy (pp. 119-125). London: A Condor Book Souvenir Press Ltd.

17. Guerra, R.M. (2010). The MARI: Reaping the essence of creativity within an arts learning organization. Excerpted, Abstract, Discussion of Findings and Conclusions and Recommendations. MA - Enterprise and Management for the Creative Arts.

18. Hervey LW. (2009). Encouraging research in dance movement therapy. In S. Chaiklin \& H. Wengrower (Eds.), The art and science of dance movement therapy (pp. 217-229). New York - London: Routhlidge.

19. What are the expressive arts? International Expressive Arts Therapy Association (IEATA). Retrieved October 17, 2012a. from http//www.ieata.org

20. Our mission. International Expressive Arts Therapy Association (IEATA). Retrieved October 17, 2012b. from http//www.ieata.org

21. Jennings, S. (1998). Introduction to dramatherapy. London \& Philadelphia: Jessica Kingsley Publishers.

22. Jones, P. (1996). Drama as Therapy. Theatre as Living. London: Routledge.

23. Karkou, V., \& Sanderson P. (2006). Arts therapies: A research-based map of the field. Edinburgh: Elsevier Churchill Livingstone. 
24. Kazim, A. (2002). Traumatic events and children: How early childhood educators can help. Association for Childhood Education International.

25. Kellerman, P.F. (1992). Focus on Psychodrama - The Thearapeutic Aspects of Psychodrama. London \& Philadelphia; Jessica Kingsley Publishers.

26. Kim, S-K., Kim, M-Y., Lee, J.-H., \& Chun S.-I. (2008): Art therapy outcomes in the rehabilitation treatment of a stroke patient: A case report. Art Therapy: Journal of the American Art Therapy Association, 25 (3), 129-133.

27. Knill, P.J., Levine, E.G., \& Levine, S.K. (2005). Principles and practice of expressive arts therapy. Jessica Kingsley Publishers.

28. Kossak, M.S. (2009). Therapeutic attunement: A transpersonal view of expressive arts therapy. The Arts in Psychotherapy, 36 (1), 13-18.

29. Krušić, V. (1992). Dramska nadarenost i njezino provjeravanje, Umjetnost $i$ dijete, 24 (5), 265-288

30. Krušić, V. (2002). Therapeutic possibilities of drama. In M. Prstačić (Eds.), Proceedings of International Symposium „Art and Scinece in Life Potential Development“ (pp. 275-280). Croatian Psychosocial Oncology Association, Faculty of Education and Rehabilitation Sciences University of Zagreb, Zagreb.

31. Lachowska, B., \& Laguna, M. (2002). Draw-A-Familiy Test in psychological research. Lubin: Katolickiego Uniwersytet.

32. Ledger, A., \& Edwards J. (2011). Arts-based research practices in music therapy research: Existing and potential. The Arts in Psychotherapy, 38 (5), 312-317.

33. Lusebrink, V.B. (2010). Assessment and therapeutic application of the expressive therapies continuum: implications for brain structures and functions. Art Therapy: Journal of the American Art Therapy Association, 27 (4), 168-177.

34. Machover, K. (1949). Personality projection: in the drawing of a human figure. Springfield, IL: Charles C Thomas Publisher.

35. Malchiodi, C.A. (1998). Understanding Children's Drawings. Guildford Publications. 
36. Malchiodi, C.A. (2012). Expressive Therapies: History, theory, and practice. In C.A. Malchodi (Eds.), Handbook of expressive therapies. New York: Guilford Press.

37. Maletić, A. (1983). Pokret i ples. Zagreb:Kulturno-prosvjetni sabor Hrvatske.

38. Martinec, R. (1995). Evaluacija nekih aspekata doživljaja sebe nakon mastektomije. Defektologija, 32 (1-2), 65-73.

39. Montello, L M., \& Coons, E.E. (1998). Effect of active versus passive group music therapy on preadolescents with emotional, learning, and behavioural disorders. Journal of Music Therapy, 35, 49-67.

40. Newlove, J., \& Dalby J. (2004). Laban for all. London: Nick Hern Books.

41. Pehrsson, D.E., \& McMillen, P. (2005). A bibliotherapy evaluation tool: Grounding counselors in the therapeutic use of literature. The Arts in Psychotherapy, 32, 47-59.

42. Pražić, B. (1987). Crtež i slika u psihijatriji. Zagreb: Naprijed.

43. Prstačić, M., Martinec, R., Mišćević, S., \& Čepulić, M. (1991). Posredni objekt u kreativnoj terapiji djeteta s malignim oboljenjem. Defektologija, 28 (2), 17-32.

44. Pylvänäinen, P. (2010). The dance/movement therapy group in a psychiatric outpatient clinic: explorations in body image and interaction. Body, Movement and Dance in Psychotherapy, 5 (3), 219230.

45. Rüütel, E. (2002). The psychophysiological effects of music and vibroacustic stimulation. Nordic Journal of Music Therapy, 11(1), 16-26.

46. Shechtman, Z. (2009). Treating Child and Adolescent Aggresion Through bibliotherapy (The Springer Series on Human Exceptionality) (pp. 21-37), Springer Verlage.

47. Silverman, M. J. (2009). A descriptive analysis of music therapists working with consumers in substance abuse rehabilitation: current clinical practice to guide future research. The Arts In Psychotherapy, 36 (3), 123-130. 
48. Slade, P. (1954). Child Drama. London: University of London Press Ltd.

49. Tortora S. (2009). Dance movement therapy in early childhood treatment. In S. Chaiklin \& H. Wengrower (Eds.), The art and science of dance movement therapy (pp. 159-180). New York - London: Routhlidge.

50. Wigram, T. (2002). Indications in music therapy. British Journal of Music Therapy, 16 (1), 11-28.

51. What is music therapy? World Federation of Music Therapy (WFMT). Retrieved January 18, 2013. from http//www.musictherapyworld.net. 
Specijalna edukacija i rehabilitacija (Beograd), Vol. 12, br. 2. 221-240, 2013.

\title{
NEKI ASPEKTI PRIMJENE ART-EKSPRESIVNIH TERAPIJA U EDUKACIJI I REHABILITACIJI
}

\author{
Damir Miholić, Renata Martinec \\ Sveučilište u Zagrebu - Edukacijsko-rehabilitacijski fakultet
}

\section{Sažetak}

U radu su razmatrani suvremeni pristupi u različitim područjima ekspresivnih art-terapija, a odnose se na primjenu likovne terapije, glazboterapije, terapije plesom i pokretom, biblioterapije, drame i psihodrame. U tu su svrhu opisana teorijska polazišta, pojedini elementi opservacije i evaluacije, kao i specifične metode terapijske intervencije. U tom smislu prikazane su dosadašnje spoznaje o različitim aspektima primjene ekspresivnih art-terapija na temelju pregleda recentne literature i rezultata istraživanja u ovom području. Rezultati provedenih istraživanja potvrđuju da primjena ekspresivnih art-terapija može imati pozitivan utjecaj na različite aspekte psihosocijalnog funkcioniranja u osobe. Također, u svrhu koncipiranja prikladnih terapijskih pristupa naglašena je potreba daljnjih istraživanja o primjeni ove vrste terapije $u$ različitim područjima edukacije i rehabilitacije.

Ključne riječi: ekspresivne art-terapije, umjetnički mediji, metode, evaluacija

Primljeno: 05.03.2013.

Prihvaćeno: 30.04.2013. 